\title{
sciendo
}

\section{InTelligenCe Information Within CRiminal Proceedings}

\author{
Adrián Vaško ${ }^{1}$
}

\begin{abstract}
The purpose of this article is to study the possibility of using intelligence in criminal proceedings in the Slovak Republic. The author examines the current legislation related to the examined issue in the context of criminal procedural law. The aim of the study is to analyze and justify the possibility of using intelligence in criminal proceedings, especially in the taking of evidence. In the context of the current security challenges, this is a serious issue which is currently relatively little developed in theory. The author concluded that the use of intelligence information is possible and applied in criminal proceedings in the Slovak Republic. This is justified by the specific provisions of the legislation in force and by the case-law of the European Court of Human Rights. In this context, it can be expected that the importance of intelligence in criminal proceedings will increase.
\end{abstract}

\section{Keywords}

Proceedings, Taking Evidence, Intelligence, Intelligence Information

\section{Introduction}

The use of intelligence information is currently a frequently debated topic, particularly in terms of guaranteeing fundamental human rights and freedoms. The reality is that this fact affects a number of diverse factors. For example, these are factors that act in isolation in the Slovak Republic, respectively on the international level, factors resulting from the development of security situation, legal environment and others. Recently, there has been a tendency to shift from a strong protection of individual rights to increasing the importance of protecting the public interest. The Code of Criminal Procedure of the Slovak Republic, in compliance with the established rules, also allows using, within taking evidence, any information obtained under other laws and thus intelligence information. The term criminal offense means a lawful procedure of the bodies active in penal proceedings of courts, or any other persons involved in criminal proceedings, whose task is to find out without reasonable doubt whether the offense was committed and, if so, to identify its perpetrator and to impose a legal punishment or protective measure under

\footnotetext{
${ }^{1}$ Academy of the Police Force in Bratislava, Sklabinská 1, Bratislava, 835 17, Slovakia. E-mail: adrian.vasko@minv.sk.
} 
the law, the decision to execute or to provide for its execution, to decide on the claim of damages for the damaged person, while respecting the fundamental rights and freedoms of natural and legal persons. While, at the same time, to strengthen the rule of law, prevent and suppress criminal activity and educate citizens.

In the conditions of the Slovak Republic, the criminal law is procedurally regulated by a generally binding legal regulation - the Act no. 301/2005 Coll. on Criminal Code of 24 May 2005, as subsequently amended. This Act came into effect on 1 January 2006. This Act is, for its complex character, of the code-like nature. It is a general rule used for different stages of criminal proceedings, and the sources of criminal procedural law are also formed by other legislation containing standards of procedural criminal law (national, international). ${ }^{2}$

The main purpose of criminal proceedings is to regulate procedures used by the bodies active in penal proceedings (prosecutors, policemen) and the courts to ensure that criminal offenses be properly investigated and their perpetrators justly punished under the law $(S .1$ Code of Criminal Procedure). In criminal proceedings, an event that happened in the near or far past is always decided on the merits. The bodies active in penal proceedings, which have to determine whether the act that is the subject of criminal proceedings happened, whether it is a criminal offense and who is its perpetrator, have not directly observed the act of committing an offense. If this was the case, they would be disqualified from the execution of the acts of criminal proceedings due to doubts about their impartiality (S. 31(1) of the Code of Criminal Procedure).

\section{Taking evidence, Means of Evidence}

The bodies active in penal proceedings and the courts can identify the act, subject to criminal proceedings, indirectly by using other mediating factors (evidence) to reconstruct it. This special process, which is strictly and precisely regulated by the Code of Criminal Procedure, is called taking evidence. ${ }^{3}$

Reaching the very purpose of penal proceedings is impossible without making taking evidence, which is irreplaceable and decisive in this process and meaning. It is the basic element on which the individual stages of the criminal proceedings are based and the results of taking evidence depend on the decision and the level of the decision rendered.

Reliable investigation of the facts is a prerequisite for a fair, equitable and convincing decision in every criminal case. Investigating the facts of the case is the role of taking evidence, which is therefore the central issue of the entire criminal proceedings. ${ }^{4}$

The aim of taking evidence is to know all the essential facts important for further applicable procedure or for rendering a merit decision. It constitutes an essential and irreplaceable part of the criminal proceedings and is carried out at all stages of criminal proceedings. The indisputable taking evidence is that it is the only way the body active in a penal proceeding and the court has to obtain the basis for further action and decision. It is

\footnotetext{
${ }^{2}$ Ivor, Polak, Záhora (2017).

${ }^{3}$ Ivor, Polak, Záhora (2017).

${ }^{4}$ Mathern (1984).
} 
possible to learn about the act indirectly by reconstructing its course using the evidence carried out. ${ }^{5}$

The process of taking evidence can be theoretically divided into the different phases, namely: seeking evidence, executing and documenting evidence, reviewing and its evaluation.

When dealing with the issues of taking evidence in criminal proceedings, it is necessary to consider, in addition to national legislation and relevant case law, adequate international standards, in particular the Convention on the Protection of Fundamental Rights and Freedoms, as amended by the Protocols and Additional Protocols of 04/11/1950, becoming effecting for the former Czechoslovakia on 18/03/1992 and the case law of the European Court of Human Rights. The Convention also guarantees a fair trial (the Art. 6(1)) and the right of the accused to prove their guilt in a lawful manner (the Art. 6(2)), but it does not regulate explicitly taking evidence (the course, scope and other) as such. In general, it can be said that the regulation of taking evidence is primarily a matter for the contractual States and that the Convention does not prescribe any of the existing evidence systems. This approach is necessary in view of the wide variety of regulating the evidence, existing not only between the continental system and the common law system but also within these systems.

The ECHR respects national law and national courts in assessing the issues of admissibility of evidence, assessment of national courts in relation to the strength of the evidence, its relevance, the veracity and the evidential value. However, the ECHR reserves the right to examine whether the act considered in its entirety, including the execution of evidence for the benefit or disadvantage of the accused, was of a fair nature within the meaning of the Article 6 of the Convention.

The current law on evidence is anchored in the Chapter 6 of the Code of Criminal Procedure (S. 119-161). The evidence can be characterized as follows: it is a legal procedure of the bodies active in criminal procedure and the court or other persons seeking to find, secure, execute and evaluate knowledge relevant for the facts crucial for the guilt and punishment decision as well as for the procedure within proceedings. ${ }^{6}$

The subject of taking evidence is always all the facts that are important in criminal proceedings for the decision in a particular case. In each criminal case, the subject of the evidence has an individual character.

The boundaries of taking evidence are always determined by a specific case. The Act exemplifies a set of circumstances to be demonstrated in the provisions of S. 119(1) as follows:

"In criminal proceedings, it must be proven in particular

(a) Whether the act which has the particulars of a criminal offence has really occurred,

b) Whether the act was committed by the accused and on what motives,

(c) Seriousness of the offense, including the causes and conditions of its commission,

(d) Personal circumstances of the perpetrator to the extent necessary to determine the

\footnotetext{
${ }^{5}$ Ivor (2010).

${ }^{6}$ Ivor, Polak, Záhora (2017).
} 
type and extent of the punishment and the imposition of a protective measure and other decisions,

(e) Consequences of and the extent of damage caused by a criminal offense,

(f) Proceeds of a criminal act and the means of committing it, its placement, nature, status and cost."

If we want to deal with the actual process of taking evidence, it is necessary to characterize the concept of evidence and the means of proof.

In the provision of S. 119(2), the Code of Criminal Procedure stipulates the legal definition of the concept of evidence as follows: "Anything that may contribute to properly clarifying the matter and that has been obtained in a lawful manner from the means of evidence or under special act."

This definition of evidence is based on the principle that only what has been obtained in a lawful manner may be used to prove the guilt and impose the punishment. "Admissibility" or "Inadmissibility" of evidence is based on the individual stages of the criminal proceedings, the provisions of the Code of Criminal Procedure and other laws (e.g. the Infringement Act no. 372/1990 Coll., as subsequently amended, the Civil Code no. 40/1964 Coll., as subsequently amended, etc.), international treaties and decision-making process of national and international courts. Despite the fact that there is no precedent in the Slovak legal system, the settled decision-making practice of the national courts together with the Constitutional Court of the Slovak Republic as well as the European Court of Human Rights creates a legal framework affecting not only the extent, the form and the way of taking evidence.

It is not necessary that evidence that is admissible for the accusation, respectively justifying the commencement of criminal prosecution in the case is lawful to bring the accused to court, or their conviction. At each stage of the process, the material value of the evidence resulting from the form and manner of its security must be assessed. ${ }^{7}$

A procedural step through which the bodies active in criminal proceedings and the court acquire important knowledge to clarify the case is the means of evidence. In accordance with S. 119(2) of the Code of Criminal Procedure, the means of evidence is: "The means of evidence shall include, in particular, interrogation of the defendant, examination of witnesses and expert statements, verification of the testimonies on the scene, identification line-up, re-enactment, investigation attempts, examination, things and documents materially relevant for criminal proceedings, notification, information obtained using information and technical means or means of operational and search activities".

Despite the fact that the means of evidence are practically exhaustively listed in the cited provision of the Code of Criminal Procedure, the other sources of evidence provided, for example, by new scientific discoveries are not excluded. The condition that evidence may indeed be "all that may contribute to clarifying the case" is to be the evidence obtained in a lawful manner. The most recent information and technical means (electrotechnical, radio, photographic, optical, and mechanical) and other technical means and devices or their

${ }^{7}$ Krutek, Kuruczová (2013). 
files, used in a classified manner when searching for, opening and examining transported shipments and their evaluation, associated with the use of forensic methods in recording telecommunication techniques, when evaluating video or audio recordings, can be taken into consideration.

In connection with the provisions of the evidence and means of evidence, we also refer to the provision of S. 119(3) of the Code of Criminal Procedure, on the basis of which the parties may also take evidence at their own expense. Increasing the contradictory nature of the criminal proceedings required explicit emphasis on the fact that evidence can also be obtained by the parties. They must, of course, bear the costs associated with obtaining such evidence. Their reimbursement by the state is taken into consideration only if an acquittal is rendered under S. 285 (a), (b) or (c) of the Code of Criminal Procedure. ${ }^{8}$ In terms of guarantee of fundamental rights with liberties, the provision of S. 119(4) of the Code of Criminal Procedure: "Evidence obtained by means of unlawful duress or threat of duress cannot be used in the proceedings with the exception of the case when it is to be used as evidence against a person who has used duress or threat of duress".

\section{Possibilities of using intelligence information in criminal proceedings}

Reflecting on the development of crime in terms of its structure and dynamics, as well as the current developments in the area of organized crime and terrorism, the countries of the world inevitably take various new measures in the field of prevention and repression. These measures are of direct concern to provisions governing the activities of police and security authorities as well as criminal law. In Criminal Law, this is reflected in particular by highlighting and strengthening the cooperation of bodies active in criminal proceedings and courts with police and security services in criminal proceedings at all stages. The provision of intelligence information also serves as an aid to the fulfilment of the protective function of criminal law.

Achieving the purpose of criminal proceedings necessarily requires, also confirmed by practical experience, the cooperation of bodies active in criminal proceedings and courts and intelligence services. In particular, this cooperation is aimed at gathering information relevant to criminal proceedings that cannot be obtained by bodies active in criminal proceedings. The intelligence services have specific rights and means, the use of which is entrusted to their exclusive competence by the legislation. To implement it is necessary, in certain cases, to ingetize the court, which is important in terms of the subject of our work. Criminal prosecution is strictly regulated in the Slovak Republic by the Code of Criminal Procedure, the process of collecting intelligence information is not modified in the "Intelligence Laws". In the case of the intelligence services of the Slovak Republic (Slovak Information Service, Military Intelligence), the legislator precisely defined their tasks and authorizations to use specific (special) resources. By purposeful realization of their authority, intelligence services obtain information, we note that in the lawful way, which provide to specified addressees to a limited extent. Under S. 2(6) of Act no. 46/1993 Coll. on the Slovak Intelligence Service, it provides information on criminal activity to the

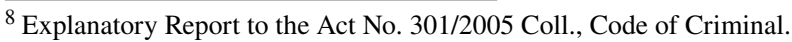


Police Corps and the Prosecutor's Office, especially on committing organized crime. It provides necessary information also to other state authorities if they need it to prevent unconstitutional, illegal activity. Such information is provided by the Slovak Information Service provided that it does not endanger the fulfilment of a particular task of the information service or detection of resources and means of the information service or identification of its members or persons acting on behalf of the information service. That does not apply if the consequence of failing to provide information is manifestly more serious than the consequences impeding if provided.

The applicable legal regulation of Military Intelligence activities is similar.

The outcome of intelligence activity in the form of intelligence information would not be important for the fulfilment of the State's protection function without its transfer to the knowledge sphere of those granted with the access under the law. The intelligence services, through their activities and their outcomes, have a significant impact on the protection and enforcement of the law when fulfilling their legal mandate. Questions related to intelligence services are relatively sensitive and do not have a clear answer even in legal theory, or legal practice. The subject of the investigation should be the nature of the intelligence information and its usefulness as evidence of evidence value. ${ }^{9}$

The use of intelligence information is currently a frequently debated topic, particularly in terms of guaranteeing fundamental human rights and freedoms. The reality is that this fact affects a number of diverse factors. For example, these are factors that act in isolation in the Slovak Republic, respectively on the international level, factors resulting from the development of security situation, legal environment and others. Therefore, finding the answer to this question cannot be done just within one country, but requires minimally a multilateral solution.

In professional literature, the admissibility of evidence is often referred to as the lawfulness of evidence. The two terms are interconnected, linked and their consistent distinction is not always possible.

The admissibility of evidence is characterized by a broader meaning than the legality of the evidence. Not every illegally obtained proof is inadmissible, but not every unacceptable evidence is illegal. Inadmissibility includes not only the inadmissibility resulting from unlawful evidence, but also the inadmissibility given by the sources of evidence and the inadmissibility of the formal cause of the time-lapse of submitting evidence by the parties to the court. ${ }^{10}$

According to legal theory, the admissibility of evidence is its essential feature, characterized in particular by compliance with the provisions of the Code of Criminal Procedure ode, the basic principles of criminal proceedings and the sources, or bearers of evidence and consistency between the provisions of the Code of Criminal Procedure, the basic principles of criminal proceedings and the methods, means and procedures used to obtain information constituting the evidence. ${ }^{11}$

\footnotetext{
${ }^{9}$ Rulíšek (2013).

10 Šimovček (2008).

${ }^{11}$ Ivor (2010).
} 
In order for some evidence to be admissible, the following rules must be observed when searching for and executing:

* Knowledge of the origin of the source of evidence, or evidence information, the possibility of verifying it

* Identifying the persons from whom the evidence information originates

* Competences of the subjects of criminal proceedings for taking of evidence

* Compliance with the general procedural rules for the search and execution of evidence

* Adherence to the rules for completeness and accuracy of the fixation of the evidence information $^{12}$

The Code of Criminal Procedure in the Slovak Republic uses the concept of legality. Legality in the given case means that a certain means of evidence is lawful and has been obtained through a process carried out by a body active in the criminal procedure and a court, which is in compliance with legal regulations. Not only the evidence, the unlawfulness was caused by, but also any evidence obtained on the basis of such evidence, is considered to be an evidence. Evidence obtained through unlawful interference with the constitutional rights of natural persons may not be used in criminal proceedings because it does not meet the conditions of the provisions of S. 119(2) of the Code of Criminal Procedure. $^{13}$

The legal theory also applies to 5 criteria for assessing the legality of the evidence quoted by Repík:

1. Whether the evidence was obtained from the source, as provided for by the law,

2. Whether the evidence was obtained and executed by a procedural subject entitled legally to do so,

3. Whether the evidence was obtained and executed at the procedural stage in which the competent processor is legally entitled to seek and execute evidence in a procedural context, i.e. such evidence which may be the basis for a decision in a criminal prosecution, in particular for a court decision,

4. Whether the evidence obtained and executed relates to the subject-matter of the proceedings, i.e. whether it relates to an act which is the subject of proceedings or to questions which are required by law to be decided on under this act,

5. Whether the evidence was obtained and executed in a manner stipulated or admitted by the law. ${ }^{14}$

From the case law of the European Court of Human Rights, it also implies that the Convention on the Protection of Human Rights and Fundamental Freedoms does not regulate evidence as such, while dealing only with a few of its aspects. Regarding the question of the admissibility of evidence, it has repeatedly emphasized that the Convention

\footnotetext{
12 Záhora (2013).

13 Záhora (2013).

${ }^{14}$ Repik (1982).
} 
does not address the issue of the admissibility of evidence and that area falls within the scope of the national law of the subjects given. ${ }^{15}$

The European Court of Human Rights further stated that the wording of Art. 6(1) of the Convention does not stipulate any rules on the admissibility of evidence and it is for the court to determine whether the proceedings were fair as a whole. However, although the European Court of Human Rights refuses to address the issue of the admissibility of evidence, in several cases it concluded that the use of certain evidence against the accused violated their right to a fair trial. ${ }^{16}$

According to Svák (2006), a lot of tendencies can be seen, including the fact that, within this context, the right to privacy is a positive commitment of the state and it extends to the sphere of interpersonal relations, there is more precise delineation of the limits or limitations of interference with the right to privacy, a preference for a national remedy for violation of the right to privacy, and an extensive interpretation concepts contained in the right to privacy. ${ }^{17}$ Gradually, the interpretative rule for the interpretation of the right to privacy became an extensive interpretation, including the right to privacy, the right to a family house, the inviolability of dwelling and the protection of correspondence.

This is also the case with the interference with the right to privacy regulated by the Convention in Art. 8. This article also states that interference with the right to privacy is permissible once the conditions are met. State authorities are entitled to interfere with this right if such interference is lawful and necessary in a democratic society in the interests of national security, public security, the country's economic well-being, the prevention of disturbances or crime, the protection of health or morals or, if necessary, rights and freedoms of others. ${ }^{18}$

It should be noted at this point that the intervention of state authorities in the right to privacy is assessed by the ECHR based on three aspects: legality, Legitimacy, proportionality.

Legality means that the competent authorities may restrict that right solely on the basis of the law, what implies directly from Art. 8 par. 2 of the Convention. When assessing compliance with the condition of legality, it is based on whether the availability and predictability of the law have been respected. ${ }^{19}$

In Article 8 par. 2) of the Convention, the legitimacy of interference with the right to privacy is directly determined. This means that the right to privacy may be affected only if it is in the interests of the public authorities to protect national security, public security, the country's economic well-being, the prevention of disturbances or crime, health or morality, or if necessary to protect rights and the freedoms of others. When assessing legitimacy, the question is whether the measure in question corresponded with a permissible objective, as mentioned above.

The proportionality of the intervention of the public authorities means that it must be respected in relation to the right to privacy and the choice of means available to the state

\footnotetext{
${ }^{15}$ Saktorová (2018).

${ }^{16}$ Mole, Harby (2006).

${ }^{17}$ Svák (2006).

${ }^{18}$ Convention on the Protection of Human Rights and Fundamental Freedoms (Art. 8 par. 1).

${ }^{19}$ Svák (2006).
} 
authorities in fulfilling the legitimate aim. In principle, state authorities have an option of exercising discretion when choosing the means by which they want to achieve a legitimate aim while being limited by the fact they will interference with the right to privacy only when it is necessary, thus in the spirit of the requirements of a democratic society. In other words, the state authorities can only intervene only when it is necessary and the objective pursued cannot be attained by any less severe means. ${ }^{20}$ That implies that the interference with the right to privacy can only be carried out if they are legal, legitimate and proportionate, and the conditions must be fulfilled at the same time.

The applicable Act no. 301/2005 Coll. on the Criminal Code within the meaning of S. 119(2) states: "It shall be possible to use as evidence anything that may contribute to properly clarifying the matter and that has been obtained in a lawful manner from the means of evidence or under special law."

This provision of the Criminal Procedure Code is, in our opinion, a basis for claiming that intelligence information obtained under special laws may serve as evidence.

In this context, we identified a number of problem areas:

* A separate act must explicitly provide that information obtained in accordance with the law may be used as evidence in criminal proceedings, respectively to govern how to proceed (e.g. the Act No. 166/2003 Coll. about the privacy protection against unauthorized use of information and technical means and the amendments and supplementations to some laws (Law on Protection against Interception)).

* It is sufficient that intelligence information was obtained under a special law (e.g. the Act no. 46/1993 on the Slovak Information Service, as subsequently amended) with court involved, as it is in cases of using information and operational means a controlled delivery, respectively false transfer of things. The use of such means is subject, in terms of approval of their use, to a legal regime under the Act no. 166/2003 Coll. on Privacy Protection against Unauthorized Use of Information and Technical Means and the amendments and supplementations to certain laws (the Interception Protection Act).

* The intelligence information obtained under a special law (e.g. the Act no. 46/1993 on the Slovak Information Service, as subsequently amended) can be used while utilizing other information and operational means (e.g. tracking people and things).

* How to approach new evidence corresponding with the level of technological development of the society in the 21 st century (satellites, GPS localization, etc.).

* The ex-post solution of the notification of persons who were affected by an intervention with the right to privacy and the right to a fair trial in accordance with the Convention.

* Seeking for optimum penetration between basic human rights and the public interest in the context of the ECHR case-law.

${ }^{20}$ Perhács, Perhácsová (2013). 


\section{Classification of Intelligence Information}

Intelligence information, as we have already characterized it, can be (in the context of criminal proceedings), in our opinion, classified according to several criteria.

Intelligence information according to the method of usage:

a) Operative-tactical information

b) Initiation for criminal proceedings

c) Evidence in criminal proceedings

Ad. (a): Intelligence information obtained and lawfully provided by bodies active in criminal proceedings can also be used in planning actions and measures as well as followup tactics. This is because the intelligence activity is not so "spooked" as criminal-law procedures, which makes it possible to use more diverse ways of obtaining information, a wider and more active use of technical means. They can often serve to guide the bodies active in criminal proceedings in conducting examinations, searching for material and documentary evidence, witnesses, etc. ${ }^{21}$

Content of intelligence information (in this context, so-called indicative) can be warnings to objects as possible sources of evidence, such as their nature, place of occurrence, method of obtaining the source of evidence, best practices, etc., information on probable behaviour of the parties in the investigation, information on the circumstances to be proven, such as enabling to solve the issue on choosing the most effective means of evidence, tactical and technical evidence-gathering procedures, data allowing correct assessment of the evidence. $^{22}$

Ad. b): Pursuant to S. 196(1) of the Act no. 301/2005 Coll. The Code of Criminal Procedure, the bodies active in criminal proceedings inspect all circumstances indicating that a criminal offense has been committed. However, incentives to initiate criminal proceedings may also come from own findings of the bodies active in criminal proceedings, or based on information provided to them, for example, by the Criminal Police Services of the Police Forces, Financial Administration of the SR, or intelligence services.

Thus, before the prosecution is initiated, it is possible to see the importance of the information received by the intelligence service, which at this stage of the criminal proceedings does not serve as evidence but it is relevant for the purposes of starting the criminal proceedings. The co-operation of the bodies active in criminal proceedings and intelligence services is therefore very important in terms of revealing the most serious forms of crime. ${ }^{23}$

Ad. c): As we have already stated in our work, taking evidence has an irreplaceable place in criminal proceedings. Under S. 119(2) of the Code of Criminal Procedure "It shall be possible to use as evidence anything that may contribute to properly clarifying the matter and that has been obtained in a lawful manner from the means of evidence or under special law."

\footnotetext{
${ }^{21}$ Čuvilev, Penzeš (1983).

${ }^{22}$ Záhora (2013).

${ }^{23}$ Ivor, Vlha (2009).
} 
In the applicable legal regulation in the Slovak Republic, we consider that there are several such laws, some of which expressly provide for the use of information, using procedures and in the manner prescribed by therein, as evidence in criminal proceedings. In some of them, such provisions are absent; however, we believe that despite this fact, the information obtained may be used as evidence.

In our opinion, the special laws in the context of S. 119(2) include:

* The Act no. 166/2003 Coll. on Privacy Protection against Unauthorized Use of Information and Technical Means and on amendments and supplementations of certain laws (the Act on Protection against Interception).

* The Act no. 1/2014 Coll. on Organizing Public Sports Events and on amendments and supplementations of certain laws.

* The Act no. 122/2013 Coll. on the Personal Data Protection and on amendments and supplementation to certain laws, or the Act no. 18/2018 Coll. on the Personal Data Protection and on amendments and supplementations to certain laws, effective as of $25 / 05 / 2018$.

* The Act no. 46/1993 Coll. on the Slovak Information Service, as subsequently amended.

* The Act no. 171/1993 Coll. on the Police, as subsequently amended.

* The Act no. 198/1994 Coll. on Military Intelligence, as subsequently amended.

* The Act no. 4/2001 Coll. on Prison and Court Guards Service, as subsequently amended.

* The Act no. 652/2004 Coll. on State Administration Bodies in Customs and on amendments and supplementation to some laws

* The Act no. 236/2017 Coll. on the European Investigation Order.

Intelligence information by the method they were obtained:

a) Information obtained through the use of information and technical means.

b) Information obtained through the use of information and operational means.

Ad. a): The regime for the use of information and technical means in the conditions of the Slovak Republic is governed by two legal regulations. One is the Act No. 301/2005 Coll. on the Criminal Code, as amended.

The second one is the Act no. 166/2003 Coll. on Privacy Protection against Unauthorized Use of Information and Technical Means and on the amendment and supplementation of certain laws (the Act on Protection against Interception). This applies to the use of information and technical means by the Police Forces, the Slovak Intelligence Service, the Military Intelligence, the Prison Corps and the Judicial Guards Corps and the Custom Administration (currently the Financial Administration of the Slovak Republic).

The Act no. 166/2003 Coll. expressly stipulates the conditions under which the information obtained may be used as evidence in criminal proceedings $(S .7(2))$.

Ad. b): The applicable legislation, namely in the case of the Slovak Information Service, S. 11 of the Act no. 46/1993 Coll. on the Slovak Information Service, includes in the information and operational means: 

a) Tracking people and things
b) Legalizing documents and caption
c) Using persons acting in the interest of the information service
d) Exchange of things
e) Fake transfer of things

The legal regulation of the use of information and operational means in the Act no. 198/1994 Coll. on Military Intelligence is similar to that of the Slovak Information Service. We believe that the information obtained by the Slovak Information Service or by the Military intelligence may be, subject to legal conditions, within the meaning of S. 119(2) of the Code of Criminal Procedure, used as evidence in criminal proceedings.

In particular, the modification of the use of information and operational means other than the legislation mentioned in the aforementioned laws is contained in the internal legal acts of the authorized entities and its content is generally classified information. In view of the above, it is not possible to deal with the use of information and operational means in details in our work.

The use of information obtained through the use of other information and operational means will require a consultation of the professional public.

Intelligence information by their origin:

a) Information obtained through the use of information and operational means and information and technical means (specific means),

b) Information obtained within international exchange of information.

Ad. a) We defined this category of information in the preceding section of our contribution. Ad. b) In this context, we would like to draw attention to the Council Framework Decision No. 2006/960/JHA of 18 December 2006 on simplifying the exchange of information and intelligence between law enforcement authorities of the EU Member States.

One of the core objectives of the European Union is to provide its citizens with a high level of security within an area of freedom, security and justice. That objective is to be achieved by preventing and combating crime through closer cooperation between law enforcement authorities in the Member States, while respecting the principles and rules relating to human rights, fundamental freedoms and the rule of law on which the Union is founded and which are common to the Member States.

Exchange of information and intelligence on crime and criminal activities is the basis for law enforcement cooperation in the Union serving the overall objective of improving the safety of the Union's citizens.

The timely access to accurate and up to date information and intelligence is a crucial element for the possibility of law enforcement authorities to successfully detect, prevent and investigate crime or criminal activity, in particular within an area where internal border controls have been abolished. As the activities of criminals are carried out clandestinely, they need to be controlled, and information relating to them needs to be exchanged particularly expeditiously. 
The common interest of Member States in fighting crime of a cross-border nature must strike the appropriate balance between fast and efficient law enforcement cooperation and agreed principles and rules on data protection, fundamental freedoms, human rights and individual liberties.

In accordance with Article (1) para. 4 of his Framework Decision does not impose any obligation on the part of the Member States to provide information and intelligence to be used as evidence before a judicial authority nor does it give any right to use such information or intelligence for that purpose. Where a Member State has obtained information or intelligence in accordance with this Framework Decision, and wishes to use it as evidence before a judicial authority, it has to obtain consent of the Member State that provided the information or intelligence, where necessary under the national law of the Member State that provided the information or intelligence, through the use of instruments regarding judicial cooperation in force between the Member States. Such consent is not required where the requested Member State has already given its consent for the use of information or intelligence as evidence at the time of transmittal of the information or intelligence.

Art. 2 (b) provides that: "criminal investigations" means a legal framework within which competent law enforcement authorities or judicial authorities, including prosecutors, take measures to find out and identify facts, suspicions and circumstances pertaining to one or more specific identified criminal offenses

Art. 2c) defines the term 'criminal intelligence operation': a procedural stage, not yet having reached the stage of a criminal investigation, within which a competent law enforcement authority is entitled by national law to collect, process and analyse information about crime or criminal activities with a view to establishing whether concrete criminal acts have been committed or may be committed in the future; ${ }^{24}$

An analogous interpretation of that document provides the following conclusions:

1. The EU Council - accepts criminal investigations - from a theoretical point of view it is possible to state in this context that the investigation of criminal offenses has an ontological and gnozeological characteristic, which the Council has also been able to perform in a methodological manner.

2. The intelligence operation in criminal matters defines, in certain contexts, the legal framework of the category, which we call terminologically in the conditions of the Slovak Republic as operative-investigation activity. While it respects that it is a subsidiary activity used to achieve partial knowledge at the pre-investigation stage.

3. In the context of this interpretation, it is important to consider that the information or intelligence information thus obtained may be used as evidence before a judicial authority with the consent of the state in which it was processed..$^{25}$

\footnotetext{
${ }^{24}$ Council Framework Decision No. 2006/960/JHA of 18 December 2006 on simplifying the exchange of information and intelligence between law enforcement authorities of the EU Member States.

${ }^{25}$ Vaško (2018).
} 
Based on the information we received during the preparation of this contribution from directed interviews with professionals from police, intelligence services and public prosecutor's office, we can state that using this type and intelligence information is relatively rare.

The list of criteria for classification of intelligence information (in the context of criminal proceedings), as we mentioned above, is not final, other criteria can also be taken into consideration (how they were obtained, the possibility of verification, etc.).

\section{Conclusion}

As it can be seen from the presented knowledge, we can conclude that the traditional approaches to address criminality and which are reflected in the Criminal Law, are almost exhausted and overcome in the context of new security challenges (international organized crime, terrorism, cybercrime, etc.). This is fully reflected in the procedural criminal law, especially in criminal proceedings. The current legislation in the Slovak Republic, in the provisions of S. 119(2) of the Act no. 301/2005 Coll. the Code of Criminal Procedure, merely exemplifies the list of the means of evidence, and therefore a priori it does not exclude the use of other means in compliance with the statutory requirements.

We believe that nowadays it is not always possible to reconstruct and capture the course of the facts using "traditional" means of evidence. Ensuring the inescapability of criminal prosecution of criminal offenders will undoubtedly require the acceptance of information as evidence obtained also from intelligence activities - thus intelligence information. In our opinion, this argument is also supported by the current legislation in the Slovak Republic. One of the milestones in this direction was the adoption of the Act No. 166/2003 Coll., explicitly establishing the possibility to use the information thus obtained as evidence in criminal proceedings.

At this point, we would like to address the issues relating to the acceptance in criminal proceedings (taking evidence) of information obtained under other laws. Searching for answers will require intense discussion of the professional public. A consensus needs to be reached on, among other, whether it is necessary for "other laws" to mention expressly that the information obtained by a process conducted in accordance with their provisions is applicable as evidence in criminal proceedings. We believe that such adjustment is not necessarily needed.

According to the current situation regarding the use of intelligence information in criminal proceedings in practice, it is possible to characterize their use as theoretically possible, but only rarely implemented.

The applicable Code of Criminal Procedure, the Act no. 301/2005 Coll., admits, according to our legal opinion, the use of intelligence information in the process of taking evidence in compliance with legal prerequisites and conditions. In this context, attention should be paid to the issues of legality, the admissibility of individual evidence in the context of national and international laws and the case-law of the European Court of Human Rights based in Strasbourg. 
From the case law of the European Court of Human Rights, it also implies that the Convention on the Protection of Human Rights and Fundamental Freedoms does not regulate evidence as such, while dealing only with a few of its aspects. Regarding the question of the admissibility of evidence, it has repeatedly emphasized that the Convention does not address the issue of the admissibility of evidence and that area falls within the scope of the national law of the subjects given.

The applicable Act no. 301/2005 Coll. on the Criminal Code within the meaning of S. 119(2) states: "It shall be possible to use as evidence anything that may contribute to properly clarifying the matter and that has been obtained in a lawful manner from the means of evidence or under special law."

This provision of the Criminal Procedure Code is, in our opinion, a basis for claiming that intelligence information obtained under special laws may serve as evidence.

Addressing these issues will require expert discussion and, in our opinion, certain legislative, organizational and logistical changes. We believe that the question of the use of intelligence information will need to be addressed with an increased attention in the near future and that its use will be indispensable and irreplaceable for specific types of crime, particularly international and organized crime and terrorism.

The use of intelligence as a mean of initiating criminal proceedings and operative-tactical information in criminal proceedings is in the Slovak republic possible and is also used by the bodies active in criminal proceedings in this respect.

\section{References}

Čuvilev, A. A., Penzeš, L'. (1983). Organizace a činnost orgánů př́pravného řizení trestního. Praha: Vysoká škola Sboru národní bezpečnosti.

European Parliament and Council Directive (EU) 2016/681 of 27 April 2016 on the Use of Passenger Name Record $(P N R)$ for the purpose of preventing, detecting, investigation and prosecution of terrorist offenses and serious crime.

Ivor, J. et al . (2010). Trestné právo procesné. (2nd, complete and edited edition). Bratislava Iura Edition.

Ivor, J., Polák, P., Záhora, J. (2017). Trestné právo procesné 1. Bratislava: Wolters Kluwer. Ivor, J., Vlha, M. (2015). Využitie spravodajských informácií v prípravnom trestnom konaní. In: Ochrana informačných zdrojov spravodajských služieb: zborník príspevkov zo sympózia Bratislava 3. decembra 2015. Bratislava: Eurokódex. 65-71.

Krutek, Kuruczová. (2013). Trestné konanie a dokazovanie v trestnom konaní, 2013, [online]. Retrieved October 4, 2018, from http://krutekkuruczova.sk/trestne-konaniedokazovanie-2013-04-22.

Lisoň, M. (2012). Teória policajného operatívneho poznania. Bratislava: Akadémia PZ v Bratislave.

Lisoň, M., Vaško, A. (2017). Informačné výstupy z kriminálno-policajného poznania a ich akceptácia. In: Deset, M: Informácie dôležité pre trestné konanie. Praha: Leges.

Mathern, V. (1984). Dokazovanie v československom trestnom práve. Bratislava: Obzor. 
Mole, N., Harby, C. (2006). Right to a fair trial. Application Guide of Article 6 of the European Convention on Human Rights. First edition, Bratislava: Council of Europe Information Office.

Perhács, Z., Perhácsová, A. (2013). Právna úprava používania informačno-technických prostriedkov (1. čast'), Justičná revue, 65(4), 543-545.

Repik, B. (1982). Procesní důsledky porušení předpisů o dokazování v trestním řízení. Bulletin advokacie, červenec-srpen, 12.

Rulíšek, T. (2013). Trestné činy proti republike a spravodajské služby, dizertačná práca, Trnava: Trnavská univerzita. 185.

Saktorová, L. (2018). The World Court of Human Rights Feasibility Study. DANUBE: Law, Economics and Social Issues Review, 9(1), 37-47.

Stieranka, J. (2013). Spravodajská činnost'. Bratislava: Akadémia PZ v Bratislave.

Svák, J. (2011). Ochrana ludských práva v troch zväzkoch. II. zväzok. Bratislava: Eurokódex.

Svák, J. (2006). Ochrana ludských práva (z pohladu judikatúry a doktríny štrasburských orgánov ochrany práv). II. rozšírené vydanie. Bratislava: Eurokódex.

Šimovček, I.: Teoretické a praktické problémy dokazovania. In: Zborník príspevkov z celoštátnej konferencie s medzinárodnou účastou konanej dña 15. decembra 2008. Bratislava: BVŠP, 2008.

The Council Framework Decision No. 2006/960/JHA of 18 December 2006 on simplifying the exchange of information and intelligence between law enforcement authorities of the EU Member States.

The Universal Declaration of Human Rights and Freedoms of the General Assembly of the United Nations.

The International Covenant on Civil and Political Rights of 1966.

The Convention on Human Rights and Fundamental Freedoms, as amended by Additional Protocols.

The Act no. 301/2005 Coll. - Criminal Code, as subsequently amended.

The Act no. 166/2003 Coll., on the Privacy Protection against Unauthorized Use of Information and Technical Means and on the amendments and supplementation of some laws, as subsequently amended.

The Act no. 1/2014 Coll. on Organizing Public Sports Events and on amendments and supplementations to certain laws.

The Act no. 122/2013 Coll. on the Personal Data Protection and on amendments and supplementations to certain laws.

The Act no. 18/2018 Coll. on the Personal Data Protection and on amendments and supplementations to certain laws.

The Act no. 46/1993 Coll. on the Slovak Information Service, as subsequently amended. The Act no. 171/1993 Coll. on the Police, as subsequently amended.

The Act no. 198/1994 Coll. on Military Intelligence, as subsequently amended.

The Act no. 4/2001 Coll. on Prison and Court Guards Service, as subsequently amended. The Act no. 652/2004 Coll. on State Administration Bodies in Customs and on amendments and supplementations to certain laws. 
The Act no. 236/2017 Coll. on the European Investigation Order.

The Act no. 403/2004 Coll. on the European Arrest Warrant and on amendments and supplementations to certain laws.

Vaško, A. (2018). Využitie spravodajských informácií v trestnom konaní, dizertačná práca. Bratislava: Paneurópska vysoká škola. 192.

Vaško, A. (2018). Spravodajská operácia v trestných veciach. In: Aktuálne otázky aplikácie kriminálneho spravodajstva $v$ kontexte nových trendov v Európskej únii, Bratislava: Akadémia PZ v Bratislave. 65-73.

Záhora, J. a kol. (2013). Dokazovanie v trestnom konaní. 1. Vydanie. Praha: Leges. 